\title{
Forest Health in Italy: Learning From the Xylella Incursion
}

\author{
Anna Maria Vettraino ${ }^{1}$ and Alberto Santini ${ }^{2 *}$ \\ ${ }^{1}$ Department for Innovation in Biological, Agro-food and Forest Systems, Viterbo, Italy, ${ }^{2}$ Institute for Sustainable Plant \\ Protection, National Research Council, Sesto fiorentino, Italy
}

Italy has an increasing part of its territory covered by forest, particularly prone to invasion by invasive forest pathogens (IFPs) owing to the presence of many different habitats and climates. To be effective, any preventive or management tools to prevent the arrival and establishment of IFPs must be included in the framework of phytosanitary legislation. The European Union has an open-door phytosanitary system meaning that any consignment that is not specifically regulated can enter. Increasing evidence of the limitations and subsequent gaps in biosecurity with the current system. Learning from the recent outbreak of Xylella fastidiosa, we provide comments and suggestions to fill the gaps and improve the phytosanitary system in Italy.

\section{OPEN ACCESS}

Edited by:

Angus J. Carnegie,

New South Wales Department of Primary Industries, Australia

Reviewed by:

Giorgio Maresi,

Fondazione Edmund Mach, Italy Andrew M. Liebhold, Northern Research Station, USDA

Forest Service, United States

*Correspondence: Alberto Santini alberto.santini@cnr.it

Specialty section:

This article was submitted to Pests, Pathogens, and Invasions,

a section of the journal

Frontiers in Forests and Global

Change

Received: 23 April 2021

Accepted: 31 August 2021

Published: 27 September 2021

Citation:

Vettraino AM and Santini A (2021)

Forest Health in Italy: Learning From

the Xylella Incursion.

Front. For. Glob. Change 4:699393.

doi: 10.3389/ffgc.2021.699393
Keywords: European phytosanitary legislation, Italian phytosanitary service, Xylella fastidiosa, Mediterranean maquis, plant health

\section{INTRODUCTION}

Italy has 11.4 million hectares of forest covering $38 \%$ of the country, less than $1 \%$ of which are industrial plantations (Sicurezza et al., 2020). In the last five years, Italian forests have continued to expand, gaining 270.000 hectares, exploiting the abandonment of mountainous areas, and agricultural land (Figure 1). Italian forest heritage includes a wide variety of forests, each with a different species composition and with special ecological and environmental requirements; about $68 \%$ of Italian forests are subtropical, characterized by Mediterranean oaks and pines and other, minor, species, while $32 \%$ are temperate, mostly characterized by beech and Norway spruce. The health of these trees is continuously threatened by the arrival of new invasive forest pathogens (IFPs) and the re-emergence of native pathogens. The consolidation of emerging production areas on the world market, the speed of transport, the removal of customs barriers, international tourism, and the decentralization of production have led to a strong increase in the movement of people and goods at an international level, and consequently to the unintentional introduction of IFPs (Santini et al., 2013). For most of the last 70 years, increased global trade has resulted in new plant pests and pathogens invasions.

Invasive forest pathogen introductions and spread are also linked to historical and economic events (Santini et al., 2018). After the end of World War II there were massive geopolitical changes; western Europe became the market for North American products and consequently most of the introduced pathogens originated there (Santini et al., 2013). Conversely, in more recent decades, the introduction of IFPs from Asia became more significant as trade has grown. For example, Ceratocystis platani, Seiridium cardinale and Heterobasidion irregulare, all of North American origin, were introduced into Europe during World War II through the Allied supply pathways (Santini et al., 2018). In the 1990s, the lethal forest pathogen Hymenoscyphus fraxineus, arrived 

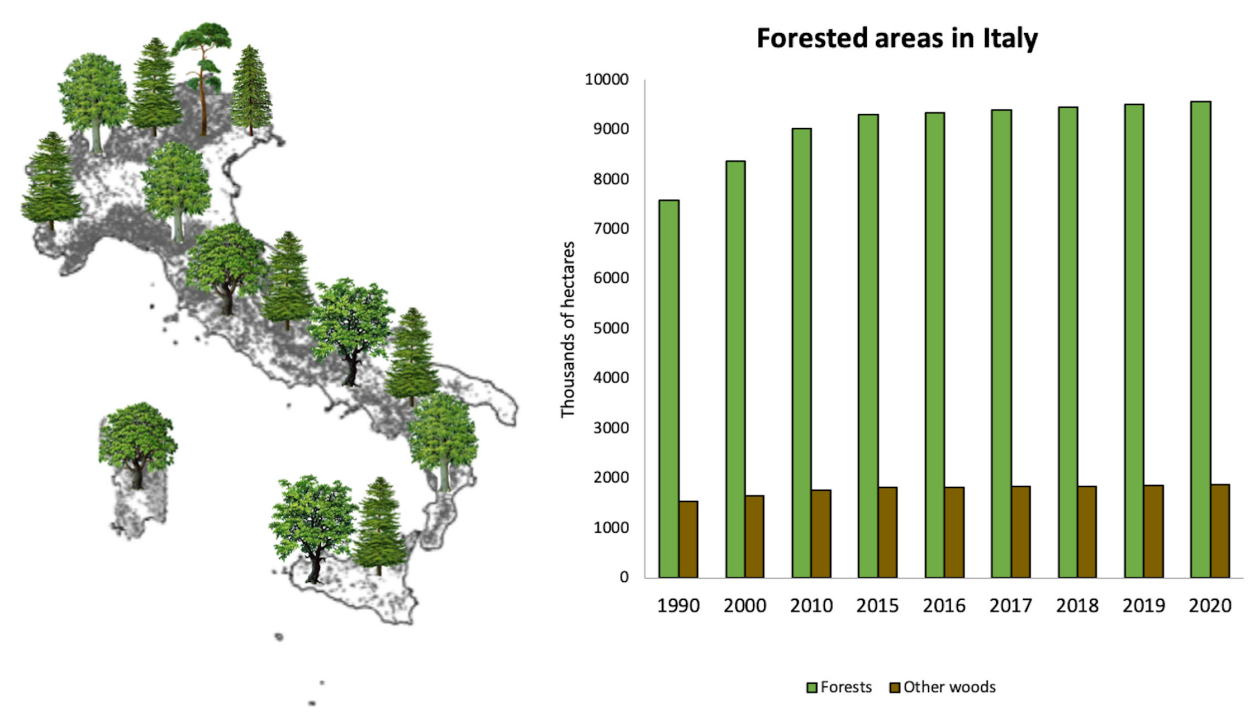

FIGURE 1 | Forested areas in Italy (data from: "National Inventory of Forests and Forest Carbon Pools-INFC", https://www.inventarioforestale.org).

in Europe from Asia, which is now one of the largest trading partner of the European Union (Kowalski, 2006)

Invasive forest pathogens are responsible for high economic losses and strong negative impacts in forest ecosystems (Moore, 2005). In some cases, financial analyses of IFPs in provisioning services have been estimated. In Sweden, for example, the damage owing to the epidemics of Ophiostoma ulmi and O. novo-ulmi (agents of Dutch elm disease) cost $€$ 9-228 million annually for about 30 years (Gren et al., 2009). The effect on the social structure of the human community and on ecosystem services, such as regulation, support and culture, on the contrary, is often neglected, even when of great impact (Lambertini et al., 2011; Kenis et al., 2017). The epidemic of chestnut blight in Europe aggravated food shortages for human populations and increased migration to urban areas (Adua, 1999). Thus, chestnut grove abandonment led to a reduction in management of these areas. As a consequence, chestnuts have been partially replaced by other species (Vannini and Vettraino, 2001; Robin et al., 2006; Conedera et al., 2016). Similarly, Ceratocystis platani, a lethal pathogen of North American origin, has significantly reduced the number of plane trees in southern Europe (Tsopelas et al., 2017).

Associations between IFPs and their hosts may shift in response to climate change, favoring host jump and pathogen expansion. Before 1990, concern about Phytophthora in EU forests was mainly associated with the mortality of sweet chestnut and beech by P. cambivora and P. cinnamomi (Brasier, 2008). Some years later, the pathogen was detected on oaks, probably enhanced by severe long summer droughts followed by late summer rains (Brasier et al., 1999). In addition, as a result of climate warming, some thermophilic species can replace less adapted species. In chestnut stands in central Italy, for example, where $P$. cambivora used to be the main pathogen, it is now outcompeted by the more adapted $P$. cinnamomi. Currently, several Phytophthora species are known to affect chestnut, beech, and oak forests (Jung et al., 2013, 2017).
Rising temperatures, changing rainfall regimes, and prolonged droughts are all stressful factors for trees, making them more susceptible to secondary native pathogens. This is the case for Diplodia sapinea, a well-known pathogen in northern Europe since the 1800s, which has only recently become a serious threat to pine forests in Sweden, Finland and the Baltic states (Fries, 1823; Müller et al., 2019). Pathogen impact is expected to increase in the future owing to the predicted climate changes and the high presence of IFPs in nurseries, and their possible spread into the wider environment (Hellmann et al., 2008; Bellard et al., 2013; Jung et al., 2017).

\section{LEGISLATIVE FRAMEWORK}

Italy adheres to the international regulations established by the main plant protection organizations such as the International Plant Protection Convention (IPPC), European and Mediterranean Plant Protection Organization (EPPO), and World Trade Organization (WTO) (Vettraino et al., 2018; World Trade Organization (WTO), 1995). National plant protection rules, in agreement with the Regulation (EU) 2016/2031 (Plant Health Law), came into force on December 14, 2019. This regulation legislates on the health of forest, agricultural and ornamental plants and it establishes the Community phytosanitary regime and specifies the phytosanitary conditions, procedures and formalities to which imports or movements of plants and plant products into the Community are subjected.

The organization of the Italian National Phytosanitary Service and related areas of competence is defined by the legislative decree August 19, 2005, no. 214 (most recently amended with Legislative Decree no. 84 of 09 April 2012). Specific mandatory control plans are the tools to eradicate or contain quarantine pests. The service is organized as a central service which takes care of implementing the EU plant health regulations into the 
Italian phytosanitary system; a total of 22 regional services apply the phytosanitary legislation across the country (Figure 2).

Italy, as a whole, features 26 harbors, 15 airports, 5 road and 4 train customs (Figure 3), with about US\$ 300 million of plant and plant product imports crossing borders annually (EU Comtrade $)^{1}$. Although Italy is not a major European importer, it is particularly prone to invasion by IFPs owing to its variety of habitats and climates, as evidenced by the 114 IFPs established since 1800 , about $60 \%$ more than the average of the other European countries (Figure 4; Santini et al., 2013 updated). Thus, phytosanitary surveys are regularly implemented at country level (Salvadori et al., 2015).

\section{RESPONSE TO XYLELLA FASTIDIOSA AS A PROOF OF CONCEPT}

In the recent past, several outbreaks of diseases caused by invasive alien pests and pathogens such as Fusarium circinatum, Hymenoscyphus fraxineus, Cydalima perspectalis, Bursaphelenchus xylophilus, and Anoplophora glabripennis, just to name a few, have impacted the European forests (Futai, 2013; Landolt et al., 2016; Vettraino et al., 2018; Javal et al., 2019). The risk of introduction of IFPs increases when an organism is polyphagous and associated with many commodities, or has a long latent phase. Xylella fastidiosa fits the description, and is the causal agent of several lethal diseases on both agricultural and forest species (European Food Safety Authority (EFSA), 2015). This pathogen has led to one of the most significant European phytosanitary emergencies in recent decades. Xylella fastidiosa is a gram negative proteobacterium

${ }^{1}$ https://comtrade.un.org/ in the family Xanthomonadaceae, native to South America. It is a complex species, and three subspecies have been formally accepted: subsp. fastidiosa, subsp. pauca and subsp. multiplex; while three others are still under revision: subsp. sandyi (on Nerium oleander), subsp. tashke (on Chitalpa tashkentensis) and subsp. morus (on Morus sp.). This bacterium colonizes both xylem tissue of host plants and the bodies of xylemfeeding insects, belonging to the order Hemiptera, which act as disease vectors (Chatterjee et al., 2008). Such insects are widely distributed so that the pathogen can easily establish new associations with local vectors (Santini and Battisti, 2019). For many years, X. fastidiosa remained confined to the Americas and only in 1993 was it first reported in Asia (Leu and $\mathrm{Su}, 1993$ ).

In 2013, X. fastidiosa subsp. pauca was detected as the agent of an unknown olive disease in the areas of Salento (Puglia, Italy), named olive quick decline syndrome (OQDS). It can infect several different host plants, including many ornamentals (e.g., Polygala myrtifolia) and Mediterranean genera (e.g., Cistus, Lavandula, Myrtus, Nerium, and Rosmarinus, etc) growing in urban and natural environments (European Food Safety Authority (EFSA), 2015). In Italy, Philaenus spumarius, a widespread native insect, is the main vector of the bacterium (Almeida and Nunney, 2015). Olive is the primary host in Europe, and the OQDS outbreak has triggered a phytosanitary crisis with devastating financial losses (up to 12 billion $€$ in six years $)^{2}$. After the first report in Italy, the pathogen was also recorded in France (European and Mediterranean Plant Protection Organization (EPPO), 2015, subsp. multiplex), Spain (European and Mediterranean Plant Protection Organization (EPPO), 2016, subsp. fastidiosa, multiplex, and pauca) and

${ }^{2}$ https://www.europarl.europa.eu/doceo/document/E-9-2019-003596_EN.html

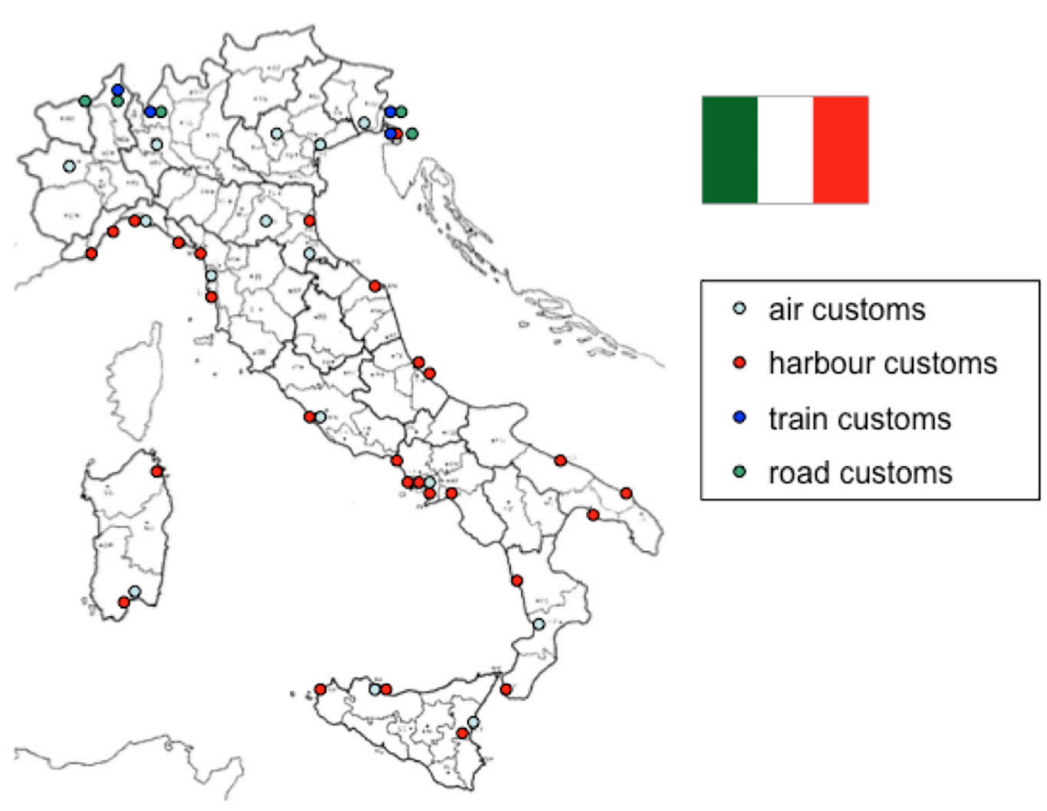

FIGURE 2 | Map of the customs locations in Italy. 

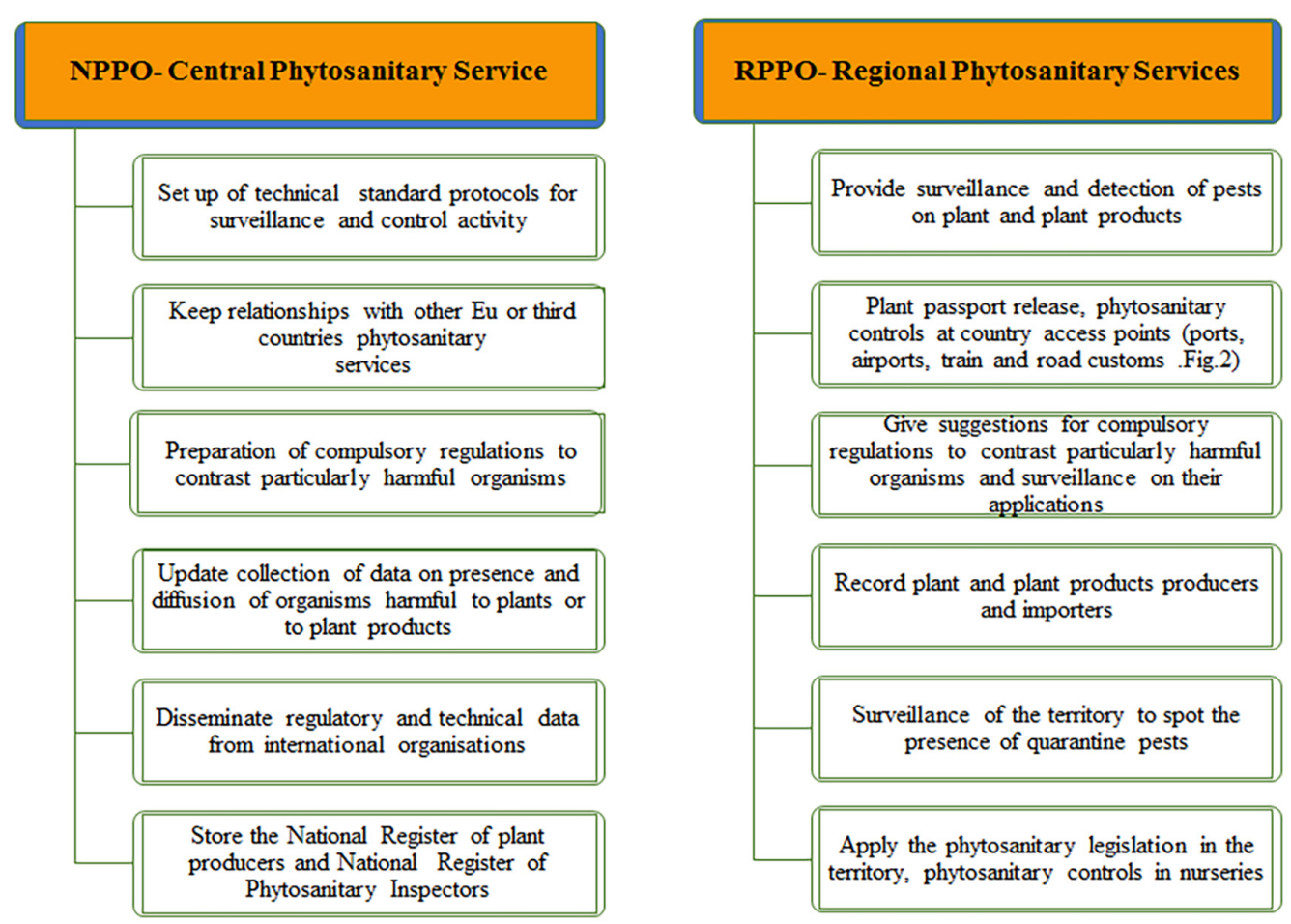

FIGURE 3 | Roles of Italian national and regional phytosanitary services.

Portugal (European and Mediterranean Plant Protection Organization (EPPO), 2019, subsp. multiplex). It has also been sporadically detected in Germany, Switzerland, and the Czech Republic (EPPO, Global database ${ }^{3}$ ). In 2018, subsp. multiplex, was detected in Toscana (Italy) on native and ornamental plants, damaging natural ecosystems, reducing the plant biodiversity of the Mediterranean maquis (Marchi et al., 2018).

\section{LEGISLATION AGAINST XYLELLA FASTIDIOSA}

In October 2013, following the first outbreak in Italy, the Commission adopted Decisions 2014/87/EU and 2014/497/EU which defined the measures to prevent the introduction to, and the spread within, the Union. These Decisions required member states to carry out annual surveys for the presence of the organism and to regulate the introduction into the EU of potential host plants from countries outside the Union and to establish demarcated areas as buffer zones around infection foci.

In 2015, the planting of the host plants in the infected zone was then prohibited, except in sites which were physically protected against the introduction of the specified organism by its vectors (Decision 2015/789/EU). Following scientific evidence and reports of new outbreak areas in different Member States, the Commission adopted new measures against X. fastidiosa (Decision 2016/764/EU; 2017/2352/EU;

${ }^{3}$ https://gd.eppo.int/
2018/927/EU; 2018/1511/EU and Commission Implementing Regulation (EU) 2020/1201). Xylella fastidiosa is now regulated in the EU as a quarantine pest (Regulation 2016/2031/EU).

At a local level, since the first report, 46 laws regarding $X$. fastidiosa have been enacted by the Puglia Regional Government.

\section{WHAT CAN WE LEARN FROM THE XYLELLA OUTBREAK?}

Xylella fastidiosa is a good example to highlight the pros and cons of the EU phytosanitary system. This invasive pest is difficult to control under normal phytosanitary systems since it has a wide host range, a long latent stage, unspecific symptoms and a complex taxonomy. Here we suggest alternative approaches to be applied at different stages associated with plant imports. These recommendations follow the various stages of the biosecurity continuum, from pre-border, to border, to post-border. Adoption of these measures will increase biosecurity in Italy and help reduce the chance of future introductions of IFPs.

\section{Pre-Border: Import Ban}

In order to prevent the accidental introduction of harmful pests, we recommend a strengthening of the import conditions for plants which may bring in cryptic pathogens that are difficult to detect during border inspections. Currently, importation of plants for planting from infected third countries is allowed if they follow the strict requirements listed in Commission 


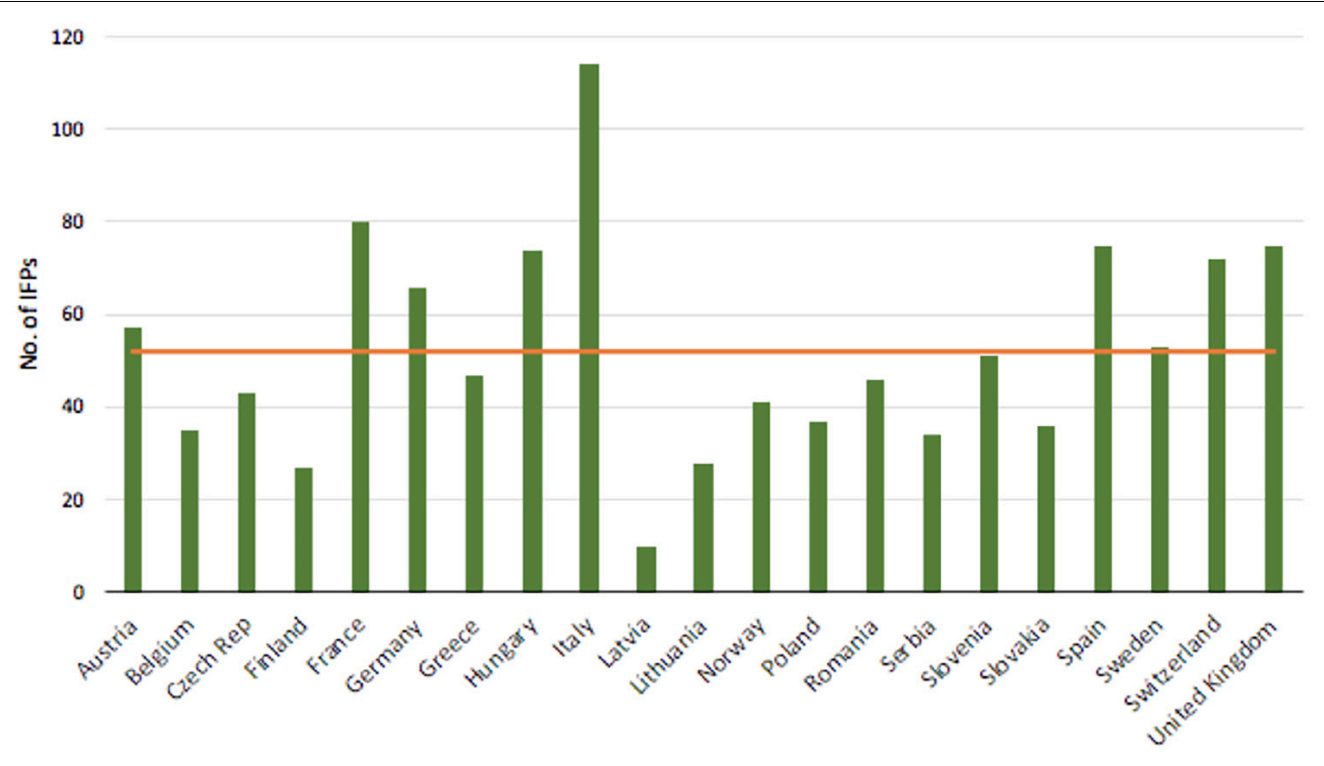

FIGURE 4 | Total number (columns) and average (line) of IFPs since 1800 (mod. from Santini et al., 2013).

Implementing Regulation (EU) 2020/1201. Specific host plant bans should be implemented using pest risk assessment (PRA). PRA and an evaluation of risk reduction options for $X$. fastidiosa was conducted in 2015 following the initial detection and outbreak. On the contrary, an import risk analysis should be assessed before importation in order to provide countries with a tool to evaluate the disease risks associated with the trade of plants. The risk assessment is prefaced by the pest categorization phase to determine whether the pest fulfils the criteria of a quarantine pest or those of a regulated non-quarantine pest for the EU. However, about $40 \%$ of IFPs established in Europe were not known as a plant threat in their country of origin, nor even known to science (Santini et al., 2013). A broader use of "sentinel" plantations should be considered. Sentinel plants are plantations of woody plants that are (i) native to the importing country and planted in the exporting country or (ii) native to the exporting country and frequently exported to the importing country (Roques et al., 2015; Vettraino et al., 2015, 2017; Eschen et al., 2019). This would help at two levels: deepen knowledge about possible new threats and make it possible to set up an appropriate PRA and, if necessary, prevent pest introduction. This approach, even if it appears to be effective, still presents some administrative difficulties for a wider application (Vettraino et al., 2020).

\section{Border}

Several constraints can affect the quality of inspections at borders, often owing to logistic and organizational challenges (Bacon et al., 2012; Eschen et al., 2015a,b; Migliorini et al., 2015). Xylella fastidiosa evaded border detection possibly because it can remain latent for long periods or cryptically present in plants not previously known as hosts, which currently include up to 595 plant species in 85 families (European Food Safety Authority (EFSA), 2020b). The EU plant health regulation does not include seeds in the list of regulated plant parts. This is owing to the fact that international seed trade is wrongly considered safer than that of other plants or plant parts (Cleary et al., 2019; Franiæ et al., 2019, 2020). However, seeds could be a pathway also for X. fastidiosa (Li et al., 2003).

To reinforce the phytosanitary system, a wider use of new accurate detection technologies, including remote sensing, volatiles, and molecular detection approaches, to enable early detection of IFPs, is reccomended (Ioos et al., 2019; Luchi et al., 2020). Since it is not realistic to rely just on border inspections, it would also be wise to impose post-entry quarantine (PEQ) to let eventual symptoms of pathogens with long latent periods to develop and/or to subject the plants to phytosanitary treatments. The importance of PEQ procedures has been recognize by about $20 \%$ of EU countries, which apply them even thought they are not compulsory (Vettraino et al., 2020).

\section{Post-Border}

Since 1981, EPPO included X. fastidiosa in the A1 quarantine pest list (List of pests recommended for regulation as quarantine pests), but the EU imposed mandatory surveys on member states only after it was discovered in Italy. This strategy brought to light the establishment of the pathogen in France, Spain and Portugal. In France the pathogen was probably introduced with ornamental plants long before the date of the first report (2015) (Denancé et al., 2017), probably in 2001 or even as far back as 1985 (Soubeyrand et al., 2018). Likewise, in Majorca the widespread dieback of almond trees that began around 2003 was initially attributed to fungal diseases (Gramaje et al., 2012); however using evidence from different sources, the introduction was backdated to 1993 (Olmo et al., 2021). These findings support the evidence that surveillance is of primary importance to assess the presence of a pathogen in a territory, as confirmed by the 
positive results obtained by single states initiatives and by the application of the EU Regulations. Since surveys are a challenge for NPPOs, especially in large and complex landscapes, new approaches have been proposed, such as the use of Unmanned Aerial Vehicle (European Food Safety Authority (EFSA), 2020a), or by aerobiological samples (Migliorini et al., 2019; Aguayo et al., 2021). Plant health authorities may enhance the likelihood of detection in surveillance programs by citizen science (Baker et al., 2019; Brown et al., 2020; Pawson et al., 2020). Interestingly, under the EU Plant Health Regulation the possibility for co-funding of the annual surveys for priority pests and also the contribution to eradication costs of quarantine pests were introduced.

\section{Effective Communication}

When Italy, according to the EU rules, applied the containment plan for $X$. fastidiosa, an unexpected problem arose that made its execution impossible: widespread media attention. Television and social media focused their attention on the $X$. fastidiosa outbreak, offering the chance to anyone to express their own idea. Public opinion divided into believers and deniers of the role of the pathogen in the death of olive trees. As sanitation fellings started, a number of farmers and common citizens protested and tried to stop the practice. A prosecutor also suspended the eradication of the disease to verify if the culls were justified as a means of stopping the spread of the disease and whether the scientists had introduced the pathogen themselves. While the ban was in force the pathogen continued to spread, and it became clear it could no longer be eradicable. The volume and forms of protest rose, fueled by conspiracy theories supported by entertainment celebrities bereft of any kind of scientific knowledge (Colella, 2016). These events are a wake-up call for biosecurity agencies to develop better outreach that translates from scientific to popular communication aimed at stakeholders and citizens about the risks of introducing new IFPs. As the $X$. fastidiosa outbreak story suggests, policymakers, scientists, and stakeholders should share the same objectives in preventing the introduction of new pathogens and applying effective management strategies. "Where ignorance is bliss, 'tis folly to be wise" (Thomas Gray, 1768).

\section{CONCLUSION}

New invasive pathogens are pressing at European borders, and since their eradication and containment is rarely successful, we should maximize efforts to prevent entry to save Europe from

\section{REFERENCES}

Adua, M. (1999). The sweet chestnut throughout history from the miocene to the third Millennium. Acta Hortic. 494, 29-36.

Aguayo, J., Husson, C., Chancerel, E., Fabreguettes, O., Chandelier, A., Fourrierjeandel, C., et al. (2021). Combining permanent aerobiological networks and molecular analyses for large-scale surveillance of forest fungal pathogens: a proof-of-concept. Plant Pathol. 70, 181-194. doi: 10.1111/ppa.13265

Almeida, R. P. P., and Nunney, L. (2015). How do plant diseases caused by Xylella fastidiosa emerge? Plant Dis. 99, 1457-1467. doi: 10.1094/PDIS-02-15-0159-FE new economic and ecological disasters. The current EU Plant health regulation has put in place some measures as obligations for the notification of outbreaks by professional operators, surveys and multiannual survey programs, demarcation of areas for the purpose of eradication, as well as enhanced requirements for priority pests, which can help to tackle this increasing problem. Such a strategy should support research in plant protection, implement technical and methodological solutions with a different conceptual approach, and change to a more science-based policy. An international agreement on phytosanitary prevention strategies would also give a new solidity to plant protection worldwide.

Xylella fastidiosa is a paradigmatic case, which clearly shows the value of keeping plants healthy by preventing the introduction of IFPs: as long as no curative or containment measures are available, the impact of the disease will have increasing repercussions on the EU economy and ecosystems.

Undoubtedly, economic costs represent one of the major challenges associated with the developing and implementing measures preventing invasions. On the other hand, managing an established pathogen is, by far, more expensive. The EU should improve its biosecurity policy by using the costs and benefits analysis of imports vs. damage from pest invasions as already adopted by different countries around the world (Eschen et al., 2015c).

\section{AUTHOR CONTRIBUTIONS}

AMV and AS conceived and wrote the manuscript. Both contributed to the article and approved the submitted version.

\section{FUNDING}

This project has received funding from the European Union's Horizon 2020 Program for Research and Innovation under grant agreement no. 771271 "HOMED."

\section{ACKNOWLEDGMENTS}

The authors wish to warmly thank Mr. Andrew Brookes for language editing and for the Thomas Gray's citation. The authors would also thank the editor and the two reviewers whose suggestions significantly increased the quality of the article.

Bacon, S. J., Bacher, S., and Aebi, A. (2012). Gaps in border controls are related to quarantine alien insect invasions in Europe. PLoS One 10:e47689. doi: 10.1371/journal.pone.0047689

Baker, E., Jeger, M. J., Mumford, J. D., and Brown, N. (2019). Enhancing plant biosecurity with citizen science monitoring: comparing methodologies using reports of acute oak decline. J. Geogr. Syst. 21, 111-131. doi: 10.1007/s10109018-0285-2

Bellard, C., Thuiller, W., Leroy, B., Genovesi, P., Bakkenes, M., and Courchamp, F. (2013). Will climate change promote future invasions? Glob. Chang. Biol. 19, 3740-3748. doi: $10.1111 /$ gcb.12344 
Brasier, C. M. (2008). The biosecurity threat to the UK and global environment from international trade in plants. Plant Pathol. 57, 792-808. doi: 10.1111/j. 1365-3059.2008.01886.x

Brasier, C. M., Cooke, D. E. L., and Duncan, J. M. (1999). Origins of a new Phytophthora pathogen through interspecific hybridisation. Proc. Natl. Acad. Sci. U.S.A. 96, 5878-5883. doi: 10.1073/pnas.96.10.5878

Brown, N., Pérez-Sierra, A., Crow, P., and Parnell, S. (2020). The role of passive surveillance and citizen science in plant health. CABI Agric. Biosci. 1:17. doi: 10.1186/s43170-020-00016-5

Chatterjee, S., Almeida, R. P., and Lindow, S. (2008). Living in two worlds: the plant and insect lifestyles of Xylella fastidiosa. Annu. Rev. Phytopathol. 46, 243-271. doi: 10.1146/annurev.phyto.45.062806.094342

Cleary, M., Oskay, F., Doğmuş, H. T., Lehtijärvi, A., Woodward, S., and Vettraino, A. M. (2019). Cryptic risks to forest biosecurity associated with the global movement of commercial seed. Forests 10:459. doi: 10.3390/f10050459

Colella, C. (2016). "Distrusting science on communication platforms: socioanthropological aspects of the science-society dialectic within a phytosanitary emergency," in Proceedings of the 2nd International Workshop on Social Media World Sensors, 10th International Conference on Language Resources and Evaluation, eds L. Di Caro, M. Cataldi, and C. Schifanella (Portoroz, Slovenia: Eur. Lang. Res. Assoc), 19-24.

Conedera, M., Tinner, W., Krebs, P., de Rigo, D., and Caudullo, G. (2016). "Castanea sativa in Europe: distribution, habitat, usage and threats," in European Atlas of Forest Tree Species, eds J. San-Miguel-Ayanz, D. de Rigo, G. Caudullo, T. Houston Durrant, and A. Mauri (Luxembourg: Publ. Off. EU).

Denancé, N., Legendre, B., Briand, M., Olivier, V., Boisseson, C., Poliakoff, F., et al. (2017). Several subspecies and sequence types are associated with the emergence of Xylella fastidiosa in natural settings in France. Plant Pathol. 66, 1054-1064. doi: 10.1111/ppa.12695

Eschen, R., Britton, K., Brockerhoff, E., Burgess, T., Dalley, V., Epanchin-Niell, R. S., et al. (2015c). International variation in phytosanitary legislation and regulations governing importation of plants for planting. Environ. Sci. Pol. 51:228e237.

Eschen, R., O’Hanlon, R., Santini, A., Vannini, A., Roques, A., Kirichenko, N., et al. (2019). Safeguarding global plant health: the rise of sentinels. J. Pest Sci. 92, 29-36. doi: 10.1007/s10340-018-1041-6

Eschen, R., Rigaux, L., Sukovata, L., Vettraino, A. M., Marzano, M., and Grégoire, J. C. (2015a). Phytosanitary inspection of woody plants for planting at European Union entry points: a practical enquiry. Biol. Invasions 17, 2403-2413. doi: 10.1007/s10530-015-0883-6

Eschen, R., Roques, A., and Santini, A. (2015b). Taxonomic dissimilarity in patterns of interception and establishment of alien arthropods, nematodes and pathogens affecting woody plants in Europe. Divers. Distrib. 21, 36-45. doi: $10.1111 /$ ddi. 12267

European Food Safety Authority (EFSA) (2015). Categorisation of plants for planting, excluding seeds, according to the risk of introduction of Xylella fastidiosa. EFSA J. 13:4061. doi: 10.2903/j.efsa.2015.4061

European Food Safety Authority (EFSA) (2020a). Minutes of the Working Group on US Oak Logs with Systems Approach for Oak Wilt. Parma: European Food Safety Authority (EFSA).

European Food Safety Authority (EFSA) (2020b). Scientific report on the update of the Xylella spp. host plant database-systematic literature search up to 30 June 2019. EFSA J. 18:6114. doi: 10.2903/j.efsa.2020.6

European and Mediterranean Plant Protection Organization (EPPO) (2015). EPPO Reporting Service (2015/144) First Report of Xylella fastidiosa in France. Kentucky, PAR: EPPO.

European and Mediterranean Plant Protection Organization (EPPO) (2016). EPPO Reporting Service (2015/213) First Report of Xylella fastidiosa in Spain. Kentucky, PAR: EPPO.

European and Mediterranean Plant Protection Organization (EPPO) (2019). EPPO Reporting Service (2015/017) First Report of Xylella fastidiosa subsp. multiplex in Portugal. Kentucky, PAR: EPPO.

Franiæ, I., Eschen, R., Allan, E., Hartmann, M., Schneider, S., and Prospero, S. (2020). Drivers of richness and community composition of fungal endophytes of tree seeds. FEMS Microbiol. Ecol. 96:fiaa166. doi: 10.1093/femsec/fiaa166

Franiæ, I., Prospero, S., Hartmann, M., Allan, E., Auger-Rozenberg, M. A., Grünwald, N. J., et al. (2019). Are traded forest tree seeds a potential source of nonnative pests? Ecol. Appl. 29:e01971. doi: 10.1002/eap.1971
Fries, E. M. (1823). Systema Mycologicum. Gryphiswaldiae : Sumtibus Ernesti Mauritii, Vol. 2. Berlin: Lund, 620.

Futai, K. (2013). Pinewood nematode, Bursaphelenchus xylophilus. Annu. Rev Phytopathol. 51:83.

Gramaje, D., Agustí-Brisach, C., Pérez-Sierra, A., Moralejo, E., Olmo, D., Mostert, L., et al. (2012). Fungal trunk pathogens associated with wood decay of almond trees on Mallorca (Spain). Persoonia Mol. Phylogeny Evol. Fungi 28, 1-13. doi: $10.3767 / 003158512$ X626155

Gray, T. (1768). "Ode on a distant prospect of Eton college," in Poems. (London: James Dodsley), 17-25.

Gren, I. M., Isacs, L., and Carlsson, M. (2009). Costs of alien invasive species in Sweden. Ambio 38, 135-140. doi: 10.1579/0044-7447-38.3.135

Hellmann, J. J., Byers, J. E., Bierwagen, B. G., and Dukes, J. S. (2008). Five potential consequences of climate change for invasive species. Conserv. Biol. 22, 534-543. doi: 10.1111/j.1523-1739.2008

Ioos, R., Aloi, F., Piškur, B., Guinet, C., Mullett, M., Berbegal, M., et al. (2019). Transferability of PCR-based diagnostic protocols: an international collaborative case study assessing protocols targeting the quarantine pine pathogen Fusarium circinatum. Sci. Rep. 9:8195. doi: 10.1038/s41598-01944672-8

Javal, M., Roques, A., Haran, J., Hérard, F., Keena, M., and Roux, G. (2019). Complex invasion history of the Asian long-horned beetle: fifteen years after first detection in Europe. J. Pest Sci. 92, 173-187. doi: 10.1007/s10340-0170917-1

Jung, T., Horta Jung, M., Cacciola, S. O., Cech, T., Bakonyi, J., Seress, D., et al. (2017). Multiple new cryptic pathogenic Phytophthora species from Fagaceae forests in Austria. IMA Fungus 8, 219-244. doi: 10.5598/imafungus.2017.08.02.02

Jung, T., Vettraino, A. M., Cech, T. L., and Vannini, A. (2013). "The impact of invasive Phytophthora species on European forests," in Phytophthora: A Global Perspective, ed. K. Lamour (Wallingford, UK: CABI), 146-158.

Kenis, M., Roques, A., Santini, A., Liebhold, A. M., and Vilà, M. (2017). "Impact of Non-native Invertebrates and Pathogens on Market Forest Tree Resources," in Impact of Biological Invasions on Ecosystem Services, Vol. 12, ed. P. E. Hulme (Cham: Invading Nature - Springer Series in Invasion Ecology), doi: 10.1007/ 978-3-319-45121-3_7 103-117

Kowalski, T. (2006). Chalara fraxinea sp. nov. associated with dieback of ash (Fraxinus excelsior) in Poland. Forest Pathol. 36, 264-270. doi: 10.1111/j.14390329.2006.00453.x

Lambertini, M., Leape, J., Marton-Lefèvre, J., Mittermeier, R. A., Rose, M., Robinson, J. G., et al. (2011). Invasives: a major conservation threat. Science 333, 404-405. doi: 10.1126/science.333.6041.404-b

Landolt, J., Gross, A., Holdenrieder, O., and Pautasso, M. (2016). Ash dieback due to Hymenoscyphus fraxineus: what can be learnt from evolutionary ecology? Plant Pathol. 65, 1056-1070. doi: 10.1111/ppa.12539

Leu, L. S., and Su, C. C. (1993). Isolation, cultivation, and pathogenicity of Xylella fastidiosa, the causal bacterium of pear leaf scorch disease in Taiwan. Plant Dis. 77, 642-646. doi: 10.1094/PD-77-0642

Li, W. B., Pria, W. D., Lacava, P. M. Jr., Qin, X., and Hartung, J. S. (2003). Presence of Xylella fastidiosa in sweet orange fruit and seeds and its transmission to seedlings. Phytopathology 93, 953-958. doi: 10.1094/PHYTO.2003.93.8.953

Luchi, N., Ioos, R., and Santini, A. (2020). Fast and reliable molecular methods to detect fungal pathogens in woody plants. Appl. Microbiol. Biotechnol. 104, 2453-2468. doi: 10.1007/s00253-020-10395-4

Marchi, G., Rizzo, D., Ranaldi, F., Ghelardini, L., Ricciolini, M., Scarpelli, I., et al. (2018). First detection of Xylella fastidiosa subsp. multiplex DNA in Tuscany (Italy). Phytopathol. Mediterr. 57, 363-364.

Migliorini, D., Ghelardini, L., Luchi, N., Capretti, P., Onorari, M., and Santini, A. (2019). Temporal patterns of airborne Phytophthora spp. in a woody plant nursery area detected using real-time PCR. Aerobiologia 35, 201-214. doi: 10. 1007/s10453-018-09551-1

Migliorini, D., Ghelardini, L., Tondini, E., Luchi, N., and Santini, A. (2015). The potential of symptomless potted plants for carrying invasive soil-borne plant pathogens. Divers. Distrib. 21, 1218-1229. doi: 10.1111/ddi.12347

Moore, B. A. (2005). Alien Invasive Species: Impacts on Forests and Forestry-A Review. Rome: Forestry Department and Forest Resource Division.

Müller, M. M., Hantula, J., Wingfield, M., and Drenkhan, R. (2019). Diplodia sapinea found on Scots pine in Finland. For. Pathol. 49:e12483. doi: 10.1111/ efp. 12483 
Olmo, D., Nieto, A., Borràs, D., Montesinos, M., Adrover, F., Pascual, A., et al. (2021). Landscape epidemiology of Xylella fastidiosa in the Balearic Islands. Agronomy 11:473. doi: 10.3390/agronomy11030473

Pawson, S. M., Sullivan, J. J., and Grant, A. (2020). Expanding general surveillance of invasive species by integrating citizens as both observers and identifiers. J. Pest Sci. 93, 1155-1166.

Robin, C., Morel, O., Vettraino, A. M., Perleroum, C., Diamandis, S., and Vannini, A. (2006). Genetic variation in susceptibility to Phytophthora cambivora in European chestnut (Castanea sativa). Ecol. Manag. 226, 199-207. doi: 10.1016/ j.foreco.2006.01.035

Roques, A., Fan, J. T., Courtial, B., Zhang, Y. Z., Yart, A., Auger-Rozenberg, M. A., et al. (2015). Planting sentinel European trees in Eastern Asia as a novel method to identify potential insect pest invaders. PLoS One 10:e120864. doi: 10.1371/journal.pone.0120864

Salvadori, C., Maresi, G., and Dellagiacoma, F. (2015). "Results and perspectives of forest health monitoring in Trentino," in Fluctuation of Insects and Diseases, Vol. 17, ed. S. Michele all'Adige (Vienna: IUFRO Methodology of Forest Insect and disease survey in Central Europe).

Santini, A., and Battisti, A. (2019). Complex insect-pathogen interactions in tree pandemics. Front. Physiol. 10:550. doi: 10.3389/fphys.2019.00550

Santini, A., Ghelardini, L., De Pace, C., Desprez-Loustau, M.-L., Capretti, P., Chandelier, A., et al. (2013). Biogeographical patterns and determinants of invasion by forest pathogens in Europe. New Phytol. 197, 238-250. doi: 10.1111/ j.1469-8137.2012.04364.x

Santini, A., Liebhold, A., Migliorini, D., and Woodward, S. (2018). Tracing the role of human civilization in the globalization of plant pathogens. ISME J. 12, 647-652. doi: 10.1038/s41396-017-0013-9

Sicurezza, B., Symbola, F., and Coldiretti e Bonifiche, F. (2020). Boschi e Foreste Nel Next Generation Europe, Sostenibilitá, Sicurezza, Bellezza. Fondazione Symbola, Coldiretti e Bonifiche Ferraresi. Ferrara.

Soubeyrand, S., De Jerphanion, P., Martin, O., Saussac, M., Manceau, C., Hendrikx, P., et al. (2018). Inferring pathogen dynamics from temporal count data: the emergence of Xylella fastidiosa in France is probably not recent. New Phytol. 219, 824-836. doi: 10.1111/nph.15177

Tsopelas, P., Santini, A., Wingfield, M., and DeBeer, W. (2017). Canker stain: A lethal disease destroying iconic plane trees. Plant Dis. 101, 645-658. doi: 10.1094/PDIS-09-16-1235-FE
Vannini, A., and Vettraino, A. M. (2001). Ink disease in chestnuts: impact on the European chestnut. For. Snow Landscape Res. 76, 345-350.

Vettraino, A. M., Li, H.-M., Eschen, R., Morales-Rodriguez, C., and Vannini, A. (2017). The sentinel tree nursery as an early warning system for pathway risk assessment: fungal pathogens associated with Chinese woody plants commonly shipped to Europe. PLoS One 12:e0188800. doi: 10.1371/journal.pone.0188800

Vettraino, A. M., Potting, R., and Raposo, R. (2018). EU legislation on forest plant health: an overview with a focus on Fusarium circinatum. Forests 9:568. doi: 10.3390/f9090568

Vettraino, A. M., Roques, A., Yart, A., Fan, J., Sun, J., and Vannini, A. (2015). Sentinel trees as a tool to forecast invasions of alien plant pathogens. PLoS One 10:e0120571. doi: 10.1371/journal.pone.0120571

Vettraino, A. M., Santini, A., Nikolov, C., Grégoire, J. C., Tomov, R., Orlinski, A., et al. (2020). A worldwide perspective of the legislation and regulations governing sentinel plants. Biol. Invasions 22, 353-362. doi: 10.1007/s10530019-02098-3

World Trade Organization (WTO) (1995). Agreement on the Application of Sanitary and Phytosanitary Measures. Rome: World Trade Organization (WTO).

Conflict of Interest: The authors declare that the research was conducted in the absence of any commercial or financial relationships that could be construed as a potential conflict of interest.

Publisher's Note: All claims expressed in this article are solely those of the authors and do not necessarily represent those of their affiliated organizations, or those of the publisher, the editors and the reviewers. Any product that may be evaluated in this article, or claim that may be made by its manufacturer, is not guaranteed or endorsed by the publisher.

Copyright (c) 2021 Vettraino and Santini. This is an open-access article distributed under the terms of the Creative Commons Attribution License (CC BY). The use, distribution or reproduction in other forums is permitted, provided the original author(s) and the copyright owner(s) are credited and that the original publication in this journal is cited, in accordance with accepted academic practice. No use, distribution or reproduction is permitted which does not comply with these terms. 